\title{
CONSERVATION
}

\section{Heterogeneity of bird communities in a mosaic of habitats on a restinga ecosystem in southeast Brazil}

\author{
Verônica S. da M. Gomes ${ }^{1,2}$, Maurício B. Vecchi², Bette A. Loiselle ${ }^{3}$, \\ Caio C.C. Missagia ${ }^{4} \&$ Maria Alice S. Alves ${ }^{2, *}$
}

\begin{abstract}
${ }^{1}$ Programa de Pós-Graduação em Ecologia, Universidade Federal do Rio de Janeiro. Ilha do Fundão, CCS, Bloco A, Sala $A 1$ 008, Caixa Postal 68020, 21941-590 Rio de Janeiro, RJ, Brazil.

${ }^{2}$ Departamento de Ecologia, IBRAG, Universidade do Estado do Rio de Janeiro. Rua São Francisco Xavier 524, Maracanã, 20550-011 Rio de Janeiro, RJ, Brazil.

${ }^{3}$ Department of Wildlife Ecology and Conservation \& Center for Latin American Studies, University of Florida. Gainesville, FL 32611, USA.

${ }^{4}$ Programa de Pós-Graduação em Ecologia e Evolução, Universidade do Estado do Rio de Janeiro. IBRAG, Rua São Francisco Xavier 524. Maracanã, 20550-011 Rio de Janeiro, RJ, Brazil.

*Corresponding author. E-mail: masaalves19@gmail.com
\end{abstract}

\begin{abstract}
Restinga occurs as a narrow band of coastal habitats throughout the Atlantic Forest, although it presents considerable variation in vegetation structure, which likely contributes to heterogeneity in species inhabiting this endangered ecosystem. The goal of this study is to examine how variation in vegetation and abiotic conditions in the restinga ecosystem may contribute to heterogeneity of bird communities in Restinga de Jurubatiba, Brazil. Temperature, relative humidity, and vegetation structure were sampled to characterize four sites (dry forest, flooded forest, open scrub and closed scrub). Birds were sampled using observations, mist-netting and voice recordings. Results indicate that major differences of all variables occur between forest and scrub in both vegetation and birds. In addition, differences also exist within forests and within scrub, resulting in considerable heterogeneity among sampled areas. Scrub sites were richer in bird species $(n=58)$ than forest sites $(n=41)$, while closed scrub had the most species $(n=49)$. Also, $64 \%$ (47 of 73 ) of bird species were exclusive to forest or scrub habitats. Scrub habitats were more similar to each other than forest habitats. Normalized Difference Vegetation Index (NDVI) calculated from satellite images distinguished scrub sites and may be useful to monitor changes in vegetation patches through time. The restinga ecosystem is quite heterogeneous with considerable turnover in bird species composition and differences in vegetation structure. Forest strips may serve as connectors on the landscape and to help maintain species diversity and conservation of forest species. Also, this highly dynamic ecosystem, which includes a mosaic of habitat types, likely promotes resilience of bird populations under changing conditions.
\end{abstract}

KEY WORDS. Avian community, NDVI, restinga forest, scrub, vegetation structure.

Marginal ecosystems in tropical forests, such as restinga in the Atlantic Forest biome, are often neglected in conservation strategies (SCARANO 2002). Restinga habitats are mosaics of vegetation physiognomies that occur throughout the Brazilian coast. These habitats vary in vegetation structure as a result of different physical, chemical and biological conditions that occur both regionally and locally (LACERDA et al. 1993). Restinga sites with similar physiognomies may be floristically distinct (MARQues et al. 2011), and the edaphic heterogeneity can favor the coexistence of plant species, increasing the regional richness (Oliveira et al. 2014).
A mosaic of habitats on the landscape is likely essential to provide resources for animals that move across the components in the landscape (LAW \& DicKMAN 1998). The heterogeneity promoted by different habitats in a landscape mosaic may ensure the presence of habitat-restricted taxa and increase community diversity (STEIN \& KREFT 2014, STEIN et al. 2014). Also, heterogeneity in vegetation structure and composition within habitats may also be important to maintain species richness and enhance ecological resilience (Tews et al. 2004, YE et al. 2013, Fleishman et al. 2002, FranZÉn \& NiLSSON 2010). Previous studies have shown that habitat characteristics may strongly influence bird diversity and 
distribution in Atlantic Forests (GoERck 1999, Gomes \& SiLva 2002, Hasur et al. 2007). More complex scrub-like habitats in restinga were richer in bird species than dune vegetation, marshes and grasslands in southern Brazil (PEDRoso-JunIor 2003) and even richer than restinga forest in northeast Brazil (MотTA et al. 2011); yet, studies within restinga habitats in southeastern Brazil are lacking.

Relative to other Atlantic forest habitats, restinga vegetation contains low levels of endemism in flora and faunal communities (RIZZINI 1979, CERQUeIra 2000, Reis \& GonZAGA 2000). Restinga avifauna, specifically, shares species with the Amazon, Caatinga, Cerrado and Chaco, although is most similar to the Atlantic Forest (ReIs \& GonZAGA 2000), especially open habitats in this biome (SICK 1997). Therefore, GonZAGA et al. (2000) suggested that bird species in restinga were probably generalists in habitat, as they occur in different biomes. Despite this resemblance with other biomes, the fauna is known to vary among the different restinga habitats, not only in birds (Alves et al. 2004), but also other vertebrates (BERGALlo et al. 2004, VAN SLuYs et al. 2004) and insects (MONTEIRo et al. 2004).

Located within Rio de Janeiro state, the Parque Nacional da Restinga de Jurubatiba (PNRJ) is considered the most preserved area of restinga in Brazil (RocHA et al. 2005, 2007). Restinga de Jurubatiba is surrounded by agriculture and cattle-raising activities, with a few isolated Atlantic forest fragments (JAMEL 2004, CARIs et al. 2013). As it is located within a largely disturbed landscape, this restinga park is an important wildlife refuge that harbors non-breeding (i.e., migrants) and threatened bird species (Alves et al. 2004, GOMEs et al. 2010).

The objective of the present study was to examine heterogeneity in bird communities within the two dominant vegetation types of restinga ecosystem in Restinga de Jurubatiba, forest and open Clusia scrub, using satellite imagery as a descriptor for restinga habitats. We expect these results contribute to identify tools to track changes in restinga habitats that might predict correspondent bird responses and help to establish conservation measures.

\section{MATERIAL AND METHODS}

Data were collected in the PNRJ $\left(22^{\circ} 17^{\prime} \mathrm{S}, 41^{\circ} 41^{\prime} \mathrm{W}\right)$, created in 1998 on the north shore of Rio de Janeiro state, included in Quissamã, Carapebus and Macaé municipalities (Fig. 1). The landscape in this region is marked by the presence of many coastal lagoons with various salinity levels. Climate is characterized by a wet season between October and April and a drier season between May and September. Mean annual rainfall is $1200 \mathrm{~mm}$ and temperature is $22.6^{\circ} \mathrm{C}$. The dominant vegetation type is Clusia scrub, formed by patches of vegetation that cover 20 to $48 \%$ of the soil and reach $5 \mathrm{~m}$ height, with few small plants in between (Henriques et al. 1986, Araujo et al. 1998). PNRJ contains a mosaic of habitat types; ten different plant communities have been recognized in the park and are associated with different nutrient concentrations and levels of water in the soil. Two communities - Clusia and Ericaceae Shrub Formations - dominate
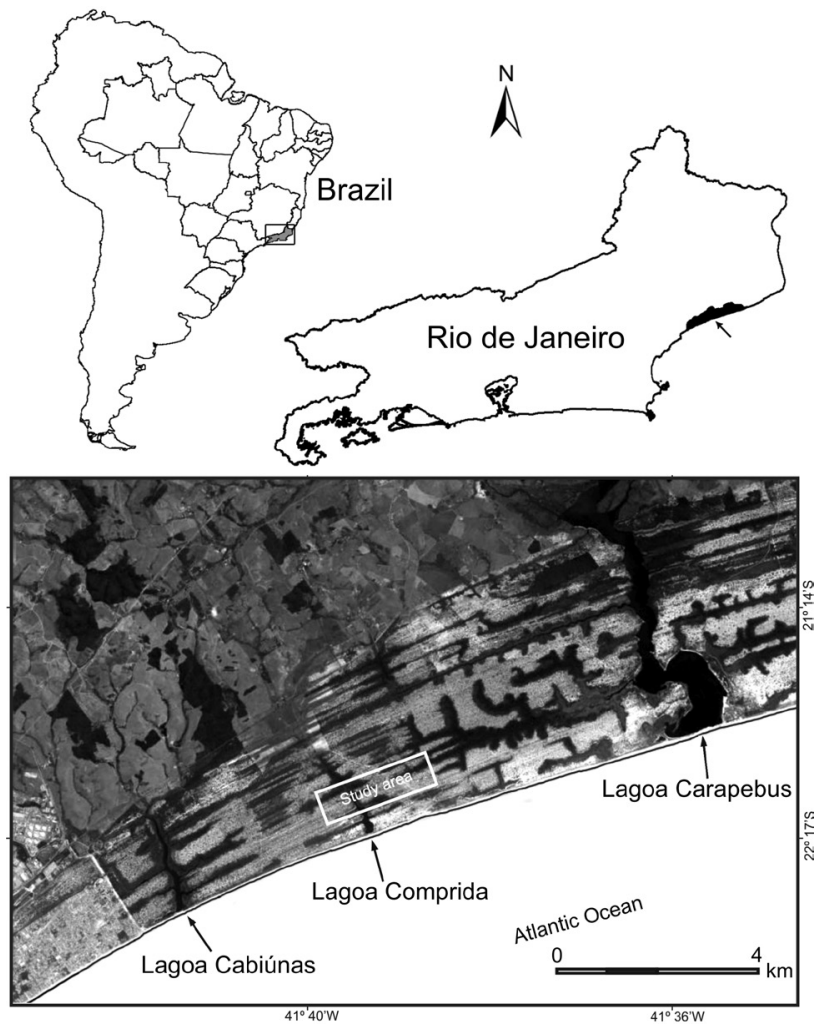

Figure 1. Location of the study area in Brazil. The arrow in Rio de Janeiro state indicates the Parque Nacional da Restinga de Jurubatiba. The four sampled sites are included in the white rectangle (Study area). Bottom map modified from Google Earth.

the park, covering more than 50\% of the area, followed by two forest plant communities (40\%) and other communities constituted by smaller-statured plants (HernRiques et al. 1986, Araujo et al. 1998, CARIs et al. 2013). The present study was developed in Clusia scrub and forest vegetation on four sites: two sites next to a lagoon called "Lagoa Comprida" (22 $16^{\prime} 41^{\prime \prime}$ S, $\left.41^{\circ} 39^{\prime} 41^{\prime \prime} \mathrm{W}\right)$ and two sites approximately two kilometers away $\left(22^{\circ} 16^{\prime} 13^{\prime \prime} \mathrm{S}\right.$, $\left.41^{\circ} 38^{\prime} 50^{\prime \prime} \mathrm{W}\right)$. Sites are hereafter called: site I - "closed scrub" (CS), site II - "flooded forest" (FF), site III - "open scrub" (OS) and site IV - "dry forest" (DF) (Figs. 2-5).

Clusia scrub on site III is more open, and has shorter vegetation than on site I, although the two sites belong to the same plant formation (Pimentel et al. 2007). Forest in site II is seasonally flooded (flooded for ten months, in the second year of study), while site IV is a forest that was never known to be flooded (Fig. 6).

Temperature, relative humidity, and vegetation structure were measured in each of the four sites.

In each site, one data logger was placed inside a wood house $(20 \mathrm{~cm}$ high $\times 15 \mathrm{~cm} \times 15 \mathrm{~cm}$, without walls to allow air circulation) to prevent rain and direct sun which could alter 

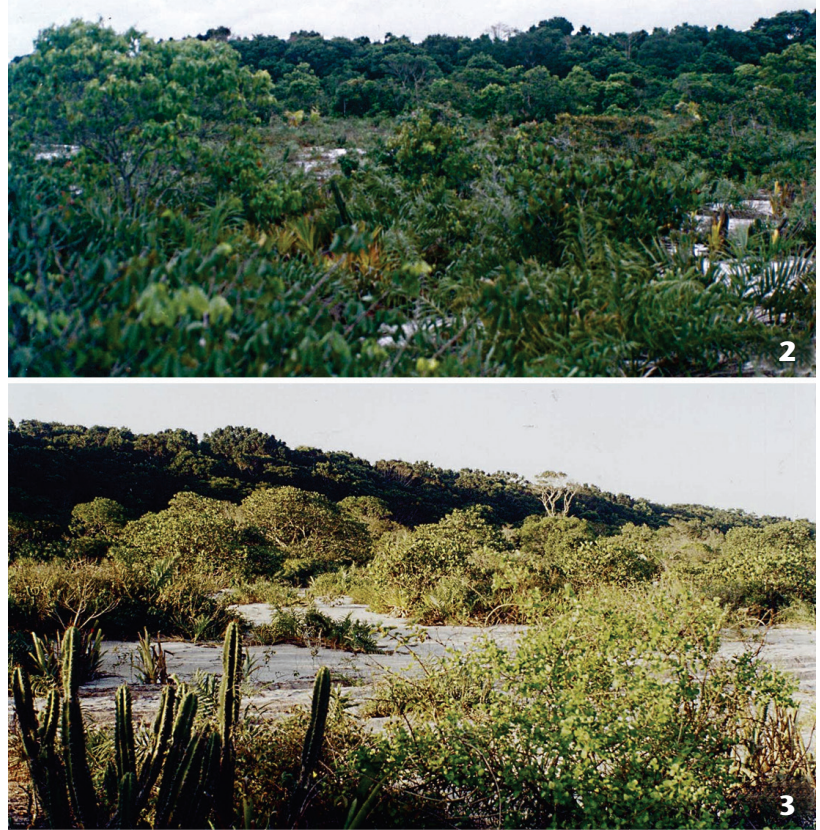

Figures 2-3. View of the study sites: (2) closed scrub (CS - site I); (3) open scrub (OS - site III). Forest sites in the background. Photos by VSMG.
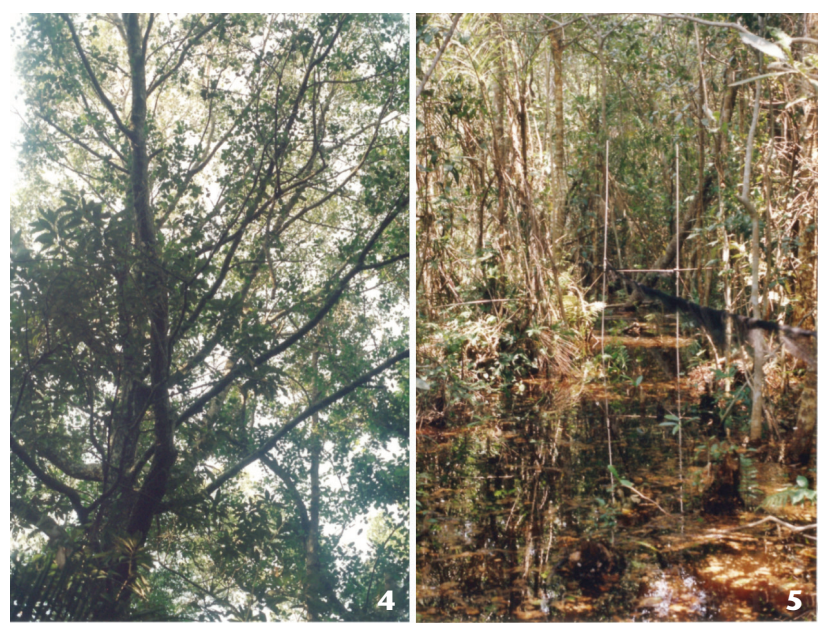

Figures 4-5. Detailed view of the: (4) dry forest (DF - site II), (5) flooded forest (FF - site IV). Photos by VSMG.

data. At any one time, two data loggers were set simultaneously in pairs of sites (one per site): closed scrub and flooded forest or open scrub and dry forest. Data loggers measured temperature

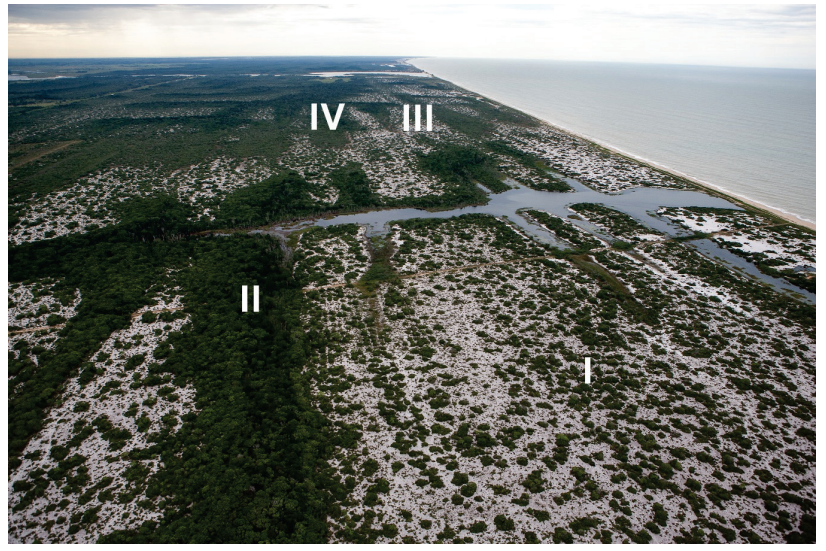

Figure 6. General view of the restinga and the sampled sites in the Parque Nacional da Restinga de Jurubatiba, Rio de Janeiro state, Brazil. Aerial photo by Romulo Campus, reproduced and ammended with his permission. I = closed scrub (CS), II = flooded forest (FF), III = open scrub (OS), IV = dry forest (DF).

and humidity every five minutes for a 24 hour period per month during nine months in each site between February 2003 and August 2004, resulting in eighteen 24-hour periods for grouped forest and eighteen for grouped scrub sites.

We used both on the ground field measurements and satellite images to characterize vegetation structure. Remote sensing has been used previously as a tool to measure vegetation characteristics (Gould 2000), as well as identify change in vegetation patterns, such as deforestation (KERR \& OSTROvSKY 2003, TURNER et al. 2003) and guide design of biological corridors and other conservation actions (TAULMAN \& SMITH 2002).

\section{Satellite image processing}

China-Brazil Earth Resource Satellite (CBERS) satellite image was obtained from Instituto Nacional de Pesquisas Espaciais (INPE), with the following specifications: Locality (scen) - Macaé, Date - 7 April 2004 (when flooded forest was flooded), Spatial resolution - $20 \mathrm{~m}$, Sensor - CCD, Spectral Bands - 2, 3 and 4 (i.e., green, red and near infrared) (Fig. S1*). The image was geocoded using Spring 3.6.02 ${ }^{\circledR}$ and points obtained in the field were then recognized. Based on those points and on the knowledge of distribution of various vegetation types on the ground, a rectangle with fixed dimensions was established for each site on the image, using Spring 3.6.02 ${ }^{\circledR}$. From each rectangle, we obtained the level of gray (LG) of the darker 30 pixels in red and infrared spectral bands, and then calculated NDVI (Normalized Difference Vegetation Index) (KerR \& OsTrovsky 2003). NDVI = (near infrared - red)/(near infrared + red). NDVI is an index of vegetation vigor as it is based on the reflectance of chlorophyll and foliar structure in red and infrared bands (KeRR \& OsTROVSKY

*Available as Online Supplementary Material with the HTML version of the article at http://www.scielo.br/zool 
2003). NDVI has been shown to be a good predictor of green biomass in dry Atlantic Forest (FreITAS et al. 2005) and is being used in this study for the first time in restinga.

\section{Field work}

The points-quadrant method was used to measure vegetation physical structure in the field (SYLVESTRE \& ROSA 2002), aiming to calculate vegetation spacing, cover and height. Between 3 and 4 July 2004, two transects ( $200 \mathrm{~m}$ long each) were established in each site, each containing 16 to 25 points and four quadrants per point. Distance between two adjacent points in the same transect was $10 \mathrm{~m}$, and transects were separated from each other by $10 \mathrm{~m}$ in forest and $50 \mathrm{~m}$ in scrub, as forests were spatially restricted to smaller areas. In each point, the following variables were collected from the nearest four plants $>50 \mathrm{~cm}$ high (one in each quadrant): distance to point, total height, and circumference at $50 \mathrm{~cm}$ above soil. In Clusia scrub sites, the only species isolated from vegetation patches that fit this criterion ( $>50 \mathrm{~cm}$ high) were Marcetia taxifolia (A.St.-Hil.) DC. (Melastomataceae) and Waltheria aspera K. Schum. (Malvaceae). In forests, a different criterion had to be applied due to the highly different vegetation architecture: trees and shrubs were measured when they had DBH at least $2.5 \mathrm{~cm}$. Number of plants sampled: $\mathrm{FF}=140, \mathrm{DF}=136, \mathrm{CR}=200, \mathrm{OR}=200$.

We focused on terrestrial and diurnal birds (excluding swifts and raptors) in this study using observations, mist-netting and voice recordings. Differences in sampling design among scrub and forest sites occurred due to differences in the spatial dispersion of forests, which were composed of thin strips of vegetation on the landscape, as seen in Fig. 6, i.e., pairs of nets and observation transects were more distant between each other in scrubs than in forests. Birds were identified using field guides (De Schauensee 1982, Dunning 1989, Ridgely \& Tudor 1994a,b, SICK 1997). Vocalizations of some species were deposited at the Arquivo Sonoro Prof. Elias Coelho (ASEC), Universidade Federal do Rio de Janeiro. In addition, for Elaenia species, some specimens were collected and compared to bird collections in Museu de Zoologia da Universidade de São Paulo (MUZUSP) and Museu Nacional do Rio de Janeiro (MNRJ).

Birds were captured under permits P029/03 (Centro Nacional de Pesquisa e Conservação de Aves Silvestres - Cemave/ Instituto Brasileiro do Meio Ambiente e dos Recursos Naturais Renováveis - IBAMA), 106/2003 and 116/2004 (Diretoria de Ecossistemas/IBAMA - Parque Nacional da Restinga de Jurubatiba). Those permits included permission for capture, transport and collection of specified bird species/families and for conduct of these activities inside the national park.

Birds were observed by VSMG walking along three parallel transects in each site between 06:00 and 12:00 h and between 13:00 and 18:00 h, totaling 50 hours in each site. Observations were conducted between September 2002 and July 2004. Each transect was approximately $200 \mathrm{~m}$ long and $50 \mathrm{~m}$ distant from any other transect in scrub sites and $10 \mathrm{~m}$ distant in forest sites. Birds perched or foraging in the vegetation were registered within a maximum horizontal distance of approximately $15 \mathrm{~m}$ in scrub sites and a maximum vertical distance of approximately $15 \mathrm{~m}$ in forest sites, where vegetation limited maximum horizontal distance to approximately $5 \mathrm{~m}$.

Birds were captured with 10 mist nets $(2.5 \times 12 \mathrm{~m}, 36 \mathrm{~mm}$ mesh) set every two months, between August 2002 and June 2004. Nets were opened from 06:00 to10:00 h and from 14:00 to $17: 00 \mathrm{~h}$, for two consecutive days, totaling 1680 net-hours in each of the four sites.

Bird songs and calls were recorded between November 2003 and July 2004 for four sessions of 15 minutes in the early morning in each site, using a directional microphone (Sennheiser ME 67) and a cassette tape-recorder (Sony TCM-5000EV), resulting in a total of one hour per site and four hours of recordings. The researcher (VSMG) arrived at the site before dawn and started recording when the first bird started singing, pointing the microphone to each distinct call or song for approximately $60 \mathrm{~s}$ (adapted from PARKER III 1991). During the recording inside forest sites, whenever birds were heard singing outside the forest, an observation was noted down. Voices were identified afterwards by one of us (MBV) using personal experience and comparison with a sound database (Xeno-canto: http://www.xeno-canto.org).

\section{Data analysis}

We compared plant height, plant basal area, distance from the point to the nearest plant and NDVI among the four sites using box plots (WILKINSON 1990). In order to examine differences in vegetation structure between habitat types and among sites, we used analysis of similarity (ANOSIM) with Primer 5 for Windows software package (CLARKE \& GORLEy 2002). The analysis was run once with habitat type as a factor (forest vs. scrub) and another time with site as a factor (flooded forest, dry forest, closed scrub, open scrub); in both cases we used Euclidean distances for similarity matrices. The variables included in the analysis were: maximum distance from a plant to the point, maximum plant height at each point and sum of basal areas at each point; the samples were each point from the point-quadrant method, grouping data from the two transects in each site (n: FF $=19$, DF $=18, \mathrm{CS}=25, \mathrm{OS}=25$ ). Satellite data were not included in these ANOSIM analyses due to differences in sampling.

To test whether environmental variables predict captures for each habitat type, we used Stepwise Multiple Regression Analysis with SYSTAT software package (WILKINSON 1990). Only the first day of capture in each month was used to avoid the influence of consecutive days in capture. Using whole-day data, plots of residuals displayed a nested design, i.e., residuals were arranged in five groups, corresponding to the five periods of sampling. Both capture and abiotic data were split into five capture periods (06:00-07:40 h, 07:41-09:20 h, 09:21h-11:00 h, 14:00-15:30 h, 15:31-17:00 h). For each period, we used the number of captures as the response variable and median of temperature, maximum temperature, minimum temperature, and median of humidity (\%) as predictor variables. The number of samples is 18 for each period for each habitat type, and nine for each site of the same habitat type. 
We used Hierarchical Cluster Analysis to group sites based on vegetation structure and bird species composition (PC-Ord, McCune \& MefFord 1999). Presence/absence of each species was used in the bird community matrix. In the vegetation matrix, the median values of the following variables were used: plant height, basal area, distance, and NDVI. We used Group average (UPGMA) as the linkage method and Bray-Curtis (Sorensen) distance measure as the similarity index for both data matrices, as they deal adequately with both qualitative and quantitative data.

\section{RESULTS}

Forest and scrub habitats are primarily distinguished by plant height (Fig. 7). Between forest sites, the dry forest has the tallest plants, though the median plant height is lower due to greater density of plants in the understory. Plant basal area also reflects a more complex understory in dry forest, as smaller stemmed plants appear in the sample. Scrub habitats are separated from each other primarily based on distance among plants; not surprisingly, in open scrub plants are more sparsely distributed as shown by greater distances from point to nearest plant. In addition, there are taller and larger diameter plants in closed scrub than in open scrub. NDVI distinguished scrub sites from each other but not forest sites, reflecting a denser foliage in forest sites and the least dense foliage in open scrub site.

Vegetation structure of forest sites grouped together and differed from scrub sites, which also clustered together (ANOSIM, $\mathrm{p}=0.001$ ) although not expressive - Global $\mathrm{R}=0.242$; high values are greater than 0.3, according to McCune \& GRACE (2002). This indicates that although there is some variation between samples, there is a significant difference between the structure of the vegetation found in forest and scrub sites. Similarly, when the four sites are compared separately, all comparisons between a forest site and a scrub site are significant, while comparisons within scrub or within forest habitats are not. Additionally, the only expressive result was obtained comparing the site with dense foliage and more complex understory (flooded forest) to the site with more sparse plants and least dense understory (open scrub) (Table 1, Fig. 7).

Table 1. Pairwise results from AnoSim based on vegetation structure among the four study sites in the Parque Nacional da Restinga de Jurubatiba. $\mathrm{FF}=$ flooded forest, $\mathrm{DF}=$ dry forest, $\mathrm{OS}=$ open scrub, CS $=$ closed scrub. In bold, both significant $(p<0.05)$ and expressive $(\mathrm{R}>0.3)$ differences.

\begin{tabular}{ccc}
\hline Comparisons & $\mathrm{R}$ & $\mathrm{P}$ \\
\hline FF $\times$ DF & -0.021 & 0.761 \\
FF $\times$ CS & 0.218 & 0.003 \\
FF $\times$ OS & $\mathbf{0 . 3 2 8}$ & $\mathbf{0 . 0 0 1}$ \\
DF $\times$ CS & 0.158 & 0.005 \\
DF $\times$ OS & 0.249 & 0.001 \\
CS $\times$ OS & -0.017 & 0.078 \\
\hline
\end{tabular}
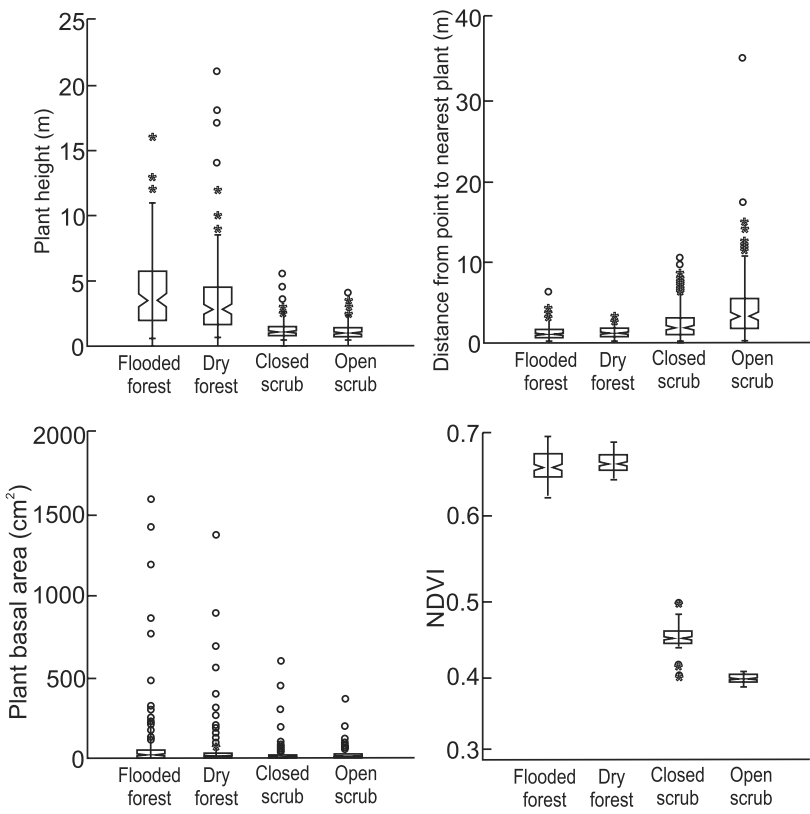

Figure 7. Box plots represent vegetation structure in the four study sites in the Parque Nacional da Restinga de Jurubatiba: vegetation index (NDVI), plant heights, basal area and distances from point-quadrant and nearest plant (internal horizontal line = median; whiskers = minimum and maximum values; box horizontal limits: inferior $=25 \%$ quartile, superior $=75 \%$ quartile; asterisks and circles $=$ two levels of outliers. Boxes are notched at the median and return to full width at the lower and upper $95 \%$ confidence limits of the median). NDVI was obtained from 30 pixels in each physiognomy. Height, basal area and distance from point to plant - number of sampled plants: flooded forest $=140$, dry forest $=136$, open scrub $=200$, closed scrub $=200$ ). Significant differences may be observed by absence of overlay among confidence intervals.

Although scrub sites may have sparser vegetation than forest sites, inside these scrub sites weather conditions were similar to forest sites (Table 2). In fact, in the middle of the day bird activity was extremely low at all sites, when they probably hide inside the patches (VSMG and MASA pers. obs.). Despite this, it was possible to detect a correlation between climatic variables and bird activity. In scrub sites, early in the morning, humidity and temperature were correlated with the number of captures with higher humidity and higher temperature leading to more captures. In contrast, during mid-day, captures declined with increasing temperatures (Table 3). In the afternoon, higher wind intensities (CPTEC 2000) likely made nets more visible in scrub sites, reducing captures and changing relationship among variables. In the forests, environmental variables were not correlated with the number of captures $\left(n=17\right.$ for each period; $\mathrm{R}^{2}$ multiple $<0.4, \mathrm{p}>0.2$ ).

Scrub sites were richer in bird species than forest sites, and closed scrub was the richest, with the same trend for site-exclu- 
sive species (Appendix 1). Voice recordings was the sole method responsible that accounted for $16 \%$ of the species in DF, $9 \%$ in $\mathrm{FF}, 6 \%$ in CS and $2 \%$ in OS. We found that $64 \%$ (47 of 73 ) of bird species were exclusive to forest or scrub habitats. Forest and scrub sites separated clearly in both vegetation structure and bird composition, while within forest or scrub, similarity values exceeded $65 \%$ (Fig. 8). Also, scrub sites were more similar to each other than were forest sites.

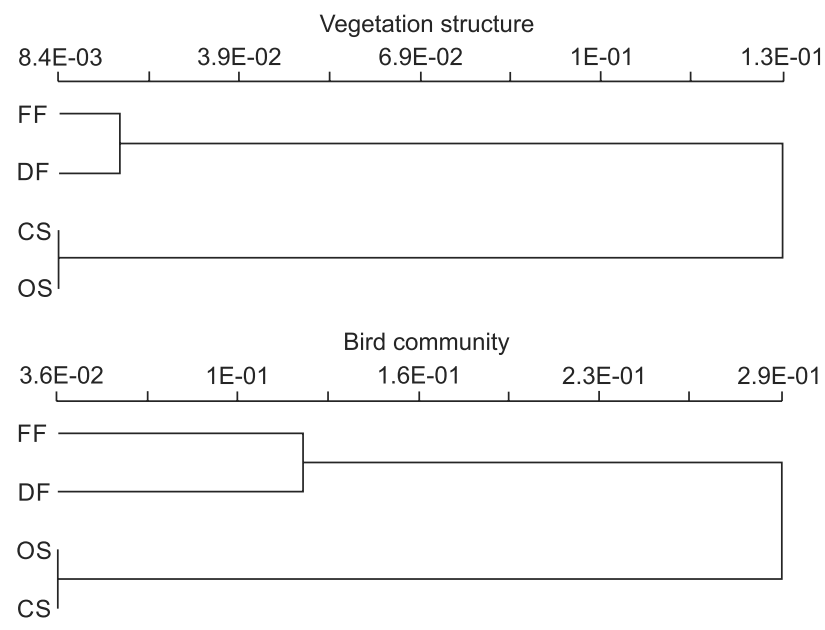

Figure 8. Cluster analysis considering vegetation structure and bird species composition in the Parque Nacional da Restinga de Jurubatiba. Scale represents dissimilarity (1-Sorensen). (FF) flooded forest, (DF) dry forest, (OS) open scrub, (CS) closed scrub.

Table 2. Summary of temperature and humidity data collected with data loggers in the Parque Nacional Restinga de Jurubatiba $(n=18$ for each site). Medians were obtained per time period each day.

\begin{tabular}{lcccc}
\hline \multicolumn{1}{c}{ Site } & \multicolumn{2}{c}{ Average of medians } & \multicolumn{2}{c}{ Temperature $\left({ }^{\circ} \mathrm{C}\right)$} \\
\hline Grouped forest sites & 74 & 24.6 & 35.0 & 13.0 \\
Flooded forest & 76 & 24.5 & 33.9 & 13.0 \\
Dry forest & 71 & 24.8 & 35.0 & 16.8 \\
Grouped scrub sites & 72 & 24.9 & 40.4 & 12.4 \\
Closed scrub & 75 & 24.8 & 34.2 & 12.4 \\
Open scrub & 69 & 25.1 & 40.4 & 13.1 \\
Overall & 73 & 24.8 & 40.4 & 12.4 \\
\hline
\end{tabular}

\section{DISCUSSION}

Results from our bird and vegetation surveys indicate that major differences exist between forest and scrub habitats, as well as between sites within forest and scrub habitats. These results suggest that there is significant habitat heterogeneity in the restinga ecosystem. The highest bird species richness found in scrub habitats contrasts with other studies which found that habitats with denser understory and greater vegetation height contain higher number of bird species (CODY 1981, RoTENBERRY 1985, TERBORGH 1985). However, results similar to ours have been found for other ecosystems as well. In a Venezuelan arid/semiarid gradient from coast to mountains (one of the driest areas of the Caribbean region) species richness was higher in the scrub vegetation than in woodland and deciduous forest (Poulin et al. 1993). Similar unexpected results between vegetation structure and species richness have been observed in an African forest and farmland comparison, where farmland open areas contain more bird species than forest, likely due to increased heterogeneity formed by mixed agricultural crops (Mulwa et al. 2012).

For restinga, Pedroso-Junior (2003) showed that more complex scrub-like habitats were richer in bird species than dune vegetation, marshes and grasslands; however, forest habitats within restinga were not included in this study. On the other hand, МотA et al. (2011) found similar results to the present study, with scrub vegetation holding more species and individuals than restinga forest on northeastern Brazil.

In the present study, the lower richness of birds in forest sites may be related to at least three factors: 1) Biogeography: restinga is composed mostly of open habitats, favoring colonization by generalist species (Gonzaga et al. 2000); 2) Floristics/ Phenology: although the most important plant species in flooded forest include ornithochoric ones (Marx de Jesus Barros unpublished data, Rodrigo Corrêa de Oliveira unpublished data), physical factors might negatively influence phenology. Only $27 \%$ ( 4 of 15) of forest exclusive bird species were predominately frugivorous and $40 \%$ ( 6 of 15 ) were insectivorous, while in scrub the tendency was reverse, with 38\% (12 of 32) predominately frugivorous and 31\% (10 of 32) insectivorous (see Appendix 1); 3) Sampling biases related to habitat structural differences: nets, observations and recordings in open and closed scrub may sample a larger area, including birds that fly over larger distances, than inside forests.

Table 3. Stepwise Multiple Regression among number of captures (log) and temperature and humidity data in each of five periods in open scrub and closed scrub in the Parque Nacional da Restinga de Jurubatiba ( $n=18$ for each period).

\begin{tabular}{|c|c|c|c|c|c|}
\hline Period (h) & $\mathrm{N}$ captures & $\mathrm{R}^{2}$ multiple & Included variables & Coefficients & $P$ \\
\hline $6: 00-7: 40$ & $0,0,2,1,7,0,12,0,0,3,0,2,2,4,6,0,0,1$ & 0.614 & Humid, Tmin & $0.035 ; 0.065$ & $0.000 ; 0.003$ \\
\hline $7: 41-9: 20$ & $8,3,13,223,4,1,9,5,0,3,5,2,5,2,10,8,12$ & 0.264 & Tmin & -0.047 & 0.029 \\
\hline $9: 21-11: 00$ & $1,1,2,4,3,7,3,7,15,0,1,2,2,4,1,1,3,7$ & 0.545 & Tmax & -0.050 & 0.000 \\
\hline $14: 00-15: 30$ & $1,0,1,0,0,0,1,0,1,1,0,0,1,1,0,0,2,2$ & 0.263 & Tmax, Tmin & $0.066 ;-0.089$ & $0.061 ; 0.040$ \\
\hline $15: 31-17: 00$ & $6,4,5,12,1,6,1,14,17,2,4,4,1,2,1,7,11,3$ & 0.181 & Humid, Tmin & $-0.047 ;-0.009$ & $0.089 ; 0.252$ \\
\hline
\end{tabular}


Despite the greater species richness in scrub sites, 15 species were found only in forests, highlighting the importance of such habitats for the restinga bird community as a whole. Recent studies in PNRJ have shown that forests harbor exclusive species that do not occur in open scrub in lepidopterans (MonTeIRo et al. 2004), amphibians (VAN SLUYs et al. 2004) and mammals (BERGALLo et al. 2004). Similarly, exclusive forest bird species have been found (seven species) in two other restinga sites (Ровто \& TEIXEIRA 1984). Although the forests in our study are submitted to an intense edge effect, being thin strips on the landscapes, they represent the majority of forests in PNRJ (CARIS et al. 2013). These elongated shapes may actually favor connectivity among forest habitats on the landscape level, which may be extremely important to maintain populations of understory bird species in the Atlantic Forest (MARTENSEN et al. 2008). Our data from marked individuals indicate that three species are especially associated with forest sites in restinga: White-crowned Manakin, Dixiphia pipra (Linnaeus, 1758), (all 11 individuals were captured in forests; a threatened species for Rio de Janeiro state; Alves et al. 2000), White-flanked Antwren, Myrmotherula axillaris (Vieillot, 1817), (all 21 individuals were captured in forests) and Sooretama Slaty-Antshrike, Thamnophilus ambiguus Swainson, 1825, (17 out of 18 individuals were captured in forests). Those three species also occur in lowland Atlantic Forest, inside two other reserves in the region (Poço das Antas Biological Reserve and União Biological Reserve) which are respectively $50 \mathrm{~km}$ and 80 km away from PNRJ (MMA/ICMBio 2008, PACHECo et al. 2010). This lowland region is highly fragmented and all forest remnants may be important to conserve forest-dependent species.

Amazonian flooded forest (Igapó) also contained fewer bird species than the surrounding natural matrix (non-flooded forest - Terra firme), although the former had a higher number of restricted species (Borges \& Carvalhaes 2000). These results suggest that similarly to restinga, habitat heterogeneity that results from biotic and abiotic processes promote overall increased species richness via the occurrence of habitat-restricted taxa (see also STEIN \& KREFT 2014 and STEIN et al. 2014).

Between forests in restinga, higher richness in flooded forest may be due to its shorter canopy (up to $15 \mathrm{~m}$ ) when compared to dry forest $(20 \mathrm{~m})$. The shorter stature of flooded forest may result in greater number of sub-canopy birds being captured in mist-nets (BeLL 1982). These results point to the importance of including voice recordings to more effectively sample dry forest bird community. In fact, species recorded by vocalization alone in DF accounted for approximately twice the percentage of species registered in FF. The presence of water in flooded forest also attracted species to the understory, such as the American Pygmy Kingfisher, Chloroceryle aenea (Pallas, 1764) and the Great Kiskadee, Pitangus sulphuratus (Linnaeus, 1766), which were probably searching for fish and tadpoles (SICK 1997). In contrast, the three most forest-dependent species cited above (D. pipra, M. axillaris and T. ambiguus) were captured more frequently in DF than in FF (see Appendix 2). Consequently, it appears that sub-canopy birds occasionally used FF understory (foraging in water), while DF contained greater abundance of forest species, likely due to its more structured architecture and apparent higher connectivity with other forests on the landscape.

Restinga forests are apparently prone to disturbances that modify their structure and likely impact their bird communities. For example, the dry forest site experienced winds of $116 \mathrm{~km} / \mathrm{h}$ on 20 June 2005 and many canopy trees fell or broke during this event. Treefalls in a forest fragment close to our study area as a result of this event were attributed to the instability of peaty soils and the shallow root systems of the trees (KuRTz et al. 2013). In addition, flooded forest can vary among years in the amount of time flooded: January to February 2003 (two months), October 2003 to July 2004 (10 months), and February to October 2005 (nine months). Prolonged floods likely result in death of some plants, altering vegetation structure randomly. In fact, flooded forests are considered soil-limited climaxes, as soil conditions limit the vegetation community to reach regional climax (SCARANO 2002) and are similar to secondary forests and climax forests gaps Souza \& Martins 2005). Araujo et al. (1998) suggest that flooded forests are at particular risk to human impacts, due to dispersal of pollutants through water and the delicate equilibrium between plant species and soil water content. They are in fact sensitive to changes in the flood regime (SCARANO et al. 1998).

Most of the studies dealing with habitat heterogeneity and bird richness have focused on the anthropogenic influence on landscape structure, with few studies focusing on natural mosaic patterns (BierregaArd et al. 1992, Stein \& Kreft 2014). The restinga forest patches of the present study may behave as artificial fragments, due to their susceptibility to disturbances and impacts; these patches may gradually lose bird species.

The restinga is a unique and fragile ecosystem. It is quite heterogeneous and highly dynamic, with considerable turnover in bird species composition and vegetation structure, which demonstrates its importance to fauna species diversity and forest species preservation on the landscape. While scrub habitats show temporal importance to birds (Gomes et al. 2010), restinga forests apparently play an important role by connecting habitats and conserving forest species on the landscape. As the restinga environment is a mosaic of habitat types, they complement each other to contribute to regional patterns of diversity. Further, these environments might also help to maintain populations of plants and animals over time, including birds, which may move among habitat types while tracking resources or environmental conditions. Consequently, the heterogeneity of habitats found within restinga might offer some degree of ecological resilience under changing conditions. We suggest that Clusia patches may be considered keystone structures in restinga scrubs, while restinga forests may be keystone structure ecosystems on the landscape level (sensu Tews et al. 2004), both promoting bird species diversity.

The present work shows that remote sensing may be useful to infer vegetation structure and guide management measures in different habitats of a heterogeneous landscape, as restinga. 
Even a mid-resolution sensor could furnish useful information on vegetation structure in such a mosaic of habitat types. NDVI may also be interesting to monitor changes in vegetation patches through time. Further work is needed to understand how resource conditions might vary over space and time and whether or not this heterogeneity in habitat conditions may actually help to maintain animal populations in this highly dynamic and threatened ecosystem.

\section{ACKNOWLEDGMENTS}

To the members of Laboratório de Ecologia de Aves, Departamento de Ecologia, Universidade do Estado do Rio de Janeiro (UERJ), and Marx J. Barros, Carlos H. Oliveira, Barbara L. Ignacio, and Renata P.N. Lima for helping in the field work. To Ricardo Gagliardi for helping with identification of part of the recorded voices. To Dorothy S.D. Araujo for helping with plant identification and important comments on the manuscript and to Luiz Antonio P. Gonzaga for helping with bird identification. To Leidemar M. Gomes for providing wood houses for data loggers and Erly S. Gomes cloth bags for birds (E.S. Gomes passed away on 9 February 2015, a beloved mother who always provided support for her daughter VSMG, this paper is dedicated to her). To Christiano Pinheiro who prepared Fig. 1. Romulo Campus kindly provided the aerial photo of the study area, and Ana Petry helped us to find and get this image. To Idea Wild for providing data loggers and mist nets. To Instituto Nacional de Pesquisas Espaciais (INPE) for supplying CBERS satellite images free of charge. To Instituto Biomas and UERJ for the vehicles used in the field. To Núcleo de Pesquisas de Macaé (NUPEM) for the logistic facilities. VSMG: Ph.D. scholarships by Coordenação de Aperfeiçoamento de Pessoal de Nível Superior (CAPES) and Fundação de Apoio à Pesquisa do Estado do Rio de Janeiro (FAPERJ). MASA: research grant by Conselho Nacional de Desenvolvimento Científico e Tecnológico (CNPq) (process number 302718/03-6), and by Fundação Carlos Chagas Filho de Amparo à Pesquisa do Estado do Rio de Janeiro (FAPERJ) (process number E-26/102837/2012). This work was also a sub-project of Grupo de Vertebrados/CNPq and PELD - site 5/CNPq.

\section{LITERATURE CITED}

Alves Mas, Pacheco JF, Gonzaga LAP, Cavalcanti RB, Raposo MA, Yamashita C, Maciel NC, Castanheira M (2000) Aves, p. 113124. In: Bergallo HG, Rocha CFD, Alves MAS, Van Sluys M (Eds.) A Fauna Ameaçada de Extinção do Estado do Rio de Janeiro. Rio de Janeiro, EdUerj, 166p.

Alves MAS, Storni A, Almeida EM, Gomes VSM, Oliveira CHP, Marques RV, Vecchi MB (2004) A comunidade de aves na Restinga de Jurubatiba, p. 199-214. In: Rocha CFD, Esteves FA, SCARANo FR (Eds.) Pesquisas ecológicas de longa duração na Restinga de Jurubatiba: Ecologia, História Natural e Conservação. São Carlos, RiMa, 374p.
Araujo DSD, Scarano FR, Sá CFC, Kurtz BC, Zaluar HLT, Montezuma RCM, Oliveira RC (1998) Comunidades Vegetais do Parque Nacional da Restinga de Jurubatiba, p. 39-62. In: Esteves FA (Ed.) Ecologia das Lagoas Costeiras do Parque Nacional da Restinga de Jurubatiba e do Município de Macaé. Rio de Janeiro, UFRJ, 442p.

BELL HL (1982) A bird community of lowland rainforest in New Guinea. 4. Birds of secondary vegetation. Emu - Austral Ornithology 82: 217-224. doi: 10.1071/MU9820217

Bergallo HG, Martins-Hatano F, Raíces DS, Ribeiro TTL, Alves AG, Luz JL, Mangolin R, Mello MAR (2004) Os mamíferos da Restinga de Jurubatiba, p. 215-230. In: Rocha CFD, Esteves FA, SCARANo FR (Eds.) Pesquisas ecológicas de longa duração na Restinga de Jurubatiba: Ecologia, História Natural e Conservação. São Carlos, RiMa, 374p.

Bierregaard Jr RO, Lovejoy TE, Kapos V, Santos AA, Hutchings RW (1992) The biological dynamics of tropical rainforest fragments. Bioscience 42: 859-866. doi: 10.2307/1312085

Borges SH, CarvalHaEs A (2000) Bird species of black water inundation forests in the Jaú National Park (Amazonas state, Brazil): their contribution to regional species richness. Biodiversity and Conservation 9: 201-214. doi: 10.1023/A:1008902306499

Caris EAP, Kurtz BC, Cruz CBM, Scarano FB (2013) Vegetation cover and land use of a protected coastal area and its surroundings, southeast Brazil. Rodriguésia 64: 747-755. doi: 10.1590/S2175-78602013000400006

Cerqueira R (2000) Biogeografia das restingas, p. 65-75. In: EsTEVES FA, LACERDA LD (Eds.) Ecologia de restingas e lagoas costeiras. Rio de Janeiro, NUPEM $\backslash$ UFRJ, 394p.

Clarke KR, Gorley RN (2002) PRIMER 5 for Windows. Plymouth, Primer E-Ltd, v. 5.2.9.

CoDy ML (1981) Habitat selection in birds: The roles of vegetation structure, competitors, and productivity. BioScience 31: 107-113. doi: $10.2307 / 1308252$

CPTEC (2000) Data from Macaé Airport, in 2000. Centro de Previsão de Tempo e Estudos Climáticos, Instituto Nacional de Pesquisas Espaciais, MCTi. Available online at: http:// sonda.cptec.inpe.br/basedados/vento_aeroportos.html [Accessed 10/06/2010]

CBRO (2014) Listas das aves do Brasil. Comitê Brasileiro de Registros Ornitológicos, $11^{\text {th }}$ ed. Available online at: $\underline{\mathrm{http}: / /}$ www.cbro.org.br/CBRO/listabr.htm [Accessed 21/01/2014]

De Schauensee RM (1982) A guide to the birds of South America. Philadelphia, The Academy of Natural Science of Philadelphia, 498p.

DunNING JS (1989) South American Birds. A photographic aid to identification. Newton Square, Harrowood Books, 315p.

Fleishman E, Ray C, Sjögren-Gulve P, Boggs CL, Murphy DD (2002) Assessing the roles of patch quality, area, and isolation in predicting metapopulation dynamics. Conservation Biology 16: 706-716. doi: 10.1046/j.1523-1739.2002.00539.x

FranzÉn M, NiLSSON SG (2010) Both population size and patch quality affect local extinctions and colonizations. Proceed- 
ings of the Royal Society of London B 277: 79-85. doi: 10.1098/rspb.2009.1584

Freitas SR, Mello MCS, Cruz CBM (2005) Relationships between forest structure and vegetation indices in Atlantic Rainforest. Forest Ecology and Management 218: 353-362. doi: 10.1016/j.foreco.2005.08.036

Goerck JM (1999) Distribution of birds along an elevational gradient in the Atlantic forest of Brazil: Implications for the conservation of endemic and endangered species. Bird Conservation International 9: 235-253. doi: 10.1017/ S0959270900003439

Gomes VSM, SILVA WR (2002) Spatial variation in understory frugivorous birds in an Atlantic Forest fragment of southeastern Brazil. Ararajuba 10: 219-225. Available online at: http:// www4.museu-goeldi.br/revistabrornito/revista/index.php/ BJO/article/view/1713

Gomes VSM, Buckeridge MS, Silva CO, Scarano FR, Araujo DSD, Alves MAS (2010) Availability peak of caloric fruits coincides with energy-demanding seasons for resident and non-breeding birds in restinga, an ecosystem related to the Atlantic forest, Brazil. Flora Morphology, Distribution, Functional Ecology of Plants 205: 647-655. doi: 10.1016/j. flora.2010.04.014

Gonzaga LP, Castiglioni GDA, Reis HBR (2000) Avifauna das restingas do Sudeste: estado do conhecimento e potencial para futuros estudos, p. 151-163. In: Esteves FA, LACERDA LD (Eds.) Ecologia de restingas e lagoas costeiras. Rio de Janeiro, NUPEM \UFRJ, 394p.

Gould W (2000) Remote sensing of vegetation, plant species richness, and regional biodiversity hotspots. Ecological Applications 10: 1861-1870. doi: 10.2307/2641244

Hasui E, Gomes VSM, SiLva WR (2007) Effects of vegetation traits on habitat preferences of frugivorous birds in Atlantic Rain Forest. Biotropica 39: 502-509. doi: 10.1111/j.17447429.2007.00299.x

Henriques RPB, Araujo DSD, Hay JD (1986) Descrição e classificação dos tipos de vegetação da restinga de Carapebus, Rio de Janeiro. Revista Brasileira de Botânica 9: 173-189.

JAMEL CEG (2004) Caracterização da vegetação da restinga de Jurubatiba com base em sensoriamento remoto e sistema de informação geográfico: estado atual e perspectivas, p. 25-42. In: Rocha CFD, Esteves FA, Scarano FR (Eds.) Pesquisas ecológicas de longa duração na Restinga de Jurubatiba: Ecologia, História Natural e Conservação. São Carlos, RiMa, 374p.

Kerr JT, Ostrovsky M (2003) From space to species: ecological applications for remote sensing. Trends in Ecology \& Evolution 18: 299-305. doi: 10.1016/S0169-5347(03)00071-5

Kurtz BC, Gomes JC, Scarano FB (2013) Structure and phytogeographic relationships of swamp forests of Southeast Brazil. Acta Botanica Brasilica 27: 647-660. doi: 10.1590/S010233062013000400002

Lacerda LD, Araújo DSD, Maciel NC (1993) Dry coastal ecosystems of the tropical Brazilian coast, p. 477-93. In: VAN DER
MaArel E (Ed.). Dry Coastal Ecosystems: Africa, America and Oceania. Amsterdam, Elsevier, 616p.

Law BS, Dickman CR (1998) The use of habitat mosaics by terrestrial vertebrate fauna: implications for conservation and management. Biodiversity \& Conservation 7: 323-333. doi: 10.1023/A:1008877611726

Marques MC, Swaine MD, Liebsch D (2011) Diversity distribution and floristic differentiation of the coastal lowland vegetation: implications for the conservation of the Brazilian Atlantic Forest. Biodiversity \& Conservation 20: 153-168. doi: 10.1007/s10531-010-9952-4

Martensen AC, Pimentel RG, Metzger JP (2008) Relative effects of fragment size and connectivity on bird community in the Atlantic Rain Forest: Implications for conservation. Biological Conservation 141: 2184-2192. doi: 10.1016/j. biocon.2008.06.008

McCune B, Mefford MJ (1999) Multivariate Analysis of Ecological Data. Gleneden Beach, MjM Software, v. 4.10.

McCune B, Grace JB (2002) Analysis of ecological communities. Gleneden Beach, MjM Software Design.

MMA/ICMBı́ (2008) Plano de Manejo - Reserva Biológica União. Encarte 3 - Análise da Unidade de Conservação. Brasília, Ministério do Meio Ambiente, Instituto Chico Mendes de Conservação da Biodiversidade, 189p.

Mota JVL, Carvalho AAF, Tinoco MS (2011) Distribuição e uso de habitat da avifauna na restinga da Reserva Imbassaí, litoral norte da Bahia. Revista Brasileira de Ornitologia 19: 364-375. Available online at: http://www4.museu-goeldi. br/revistabrornito/revista/index.php/BJO/article/view/4407

Monteiro RF, Esperanço AP, Becker VO, Otero LS, Herkenhoff EV, SoARes A (2004) Mariposas e borboletas na Restinga de Jurubatiba, p. 143-164. In: Rocha CFD, Esteves FA, SCARANo FR (Eds.) Pesquisas ecológicas de longa duração na Restinga de Jurubatiba: Ecologia, História Natural e Conservação. São Carlos, RiMa, 374p.

Mulwa RK, Böhning-Gaese K, Schleuning M (2012) High Bird Species Diversity in Structurally Heterogeneous Farmland in Western Kenya. Biotropica 44: 801-809. doi: 10.1111/j.17447429.2012.00877.x

Oliveira AA, Vicentini A, Chave J, Castanho CDT, Davies SJ, Martini AMZ, Lima RAF, Ribeiro RR, Iribar A, Souza VC (2014) Habitat specialization and phylogenetic structure of tree species in a coastal Brazilian white-sand forest. Journal of Plant Ecology 7: 134-144. doi: 10.1093/jpe/rtt073

Pacheco JF, Castro-Astor IN, Bauer C (2010) Avifauna da Reserva Biológica de Poço das Antas, Silva Jardim, RJ. Atualidades Ornitológicas 157: 55-74.

PARKer III TA (1991) On the use of tape recorders in avifaunal surveys. The Auk 108: 443-444.

Pedroso-Junior NN (2003) Microhabitat occupation by birds in a restinga fragment of Paraná coast, PR, Brazil. Brazilian Archives of Biology and Technology 46: 83-90. doi: 10.1590/ S1516-89132003000100013 
Pimentel MCP, Barros MJ, Cirne P, Mattos EA, Oliveira RC, Pereira MCA, Scarano FR, Zaluar HLT, Araujo DSD (2007) Spatial variation in the structure and floristic composition of "restinga" vegetation of southeastern Brazil. Brazilian Journal of Botany 30: 543-351. doi: 10.1590/S0100-84042007000300018

Porto FCS, TeIxeIra DM (1984) Um estudo comparativo preliminar sobre as avifaunas das restingas do leste do Brasil, p. 343-349. In: Lacerda LD, Araujo DSD, Cerqueira R, Turce B (Eds.) Restingas: origens, estruturas, processos. Niterói, CEUFF, 477p.

Poulin B, Lefebvre G, McNeil R (1993) Variations in bird abundance in tropical arid and semi-arid habitats. Ibis 135: 432441. doi: 10.1111/j.1474-919X.1993.tb02116.x

Reis HBR, GonZaga LP (2000) Análise da distribuição geográfica das aves das restingas do Estado do Rio de Janeiro, p. 165178. In: EsTeves FA, LACERDA LD (Eds.) Ecologia de restingas e lagoas costeiras. Rio de Janeiro, NUPEM \UFRJ, 394p.

Ridgely RS, Tudor G 1994a. The birds of South America. Austin, University of Texas Press, vol. 1, 516p.

Ridgely R S, Tudor G 1994b. The birds of South America. Austin, University of Texas Press, vol. 2, 814p.

RizzINI CT (1979) Tratado de fitogeografia do Brasil: aspectos sociológicos e florísticos. São Paulo, Universidade de São Paulo, 375p.

Rocha CFD, Sluys MV, Bergallo HG, Alves MAS (2005) Endemic and threatened tetrapods in the restingas of the biodiversity corridors of Serra do Mar and of the Central da Mata Atlântica in eastern Brazil. Brazilian Journal of Biology 65: 159-168. doi: 10.1590/S1519-69842005000100019

Rocha CFD, Bergallo HG, Sluys MV, Alves MAS, Jamel CE (2007) The remnants of restinga habitats in the Brazilian Atlantic forest of Rio de Janeiro state, Brazil: habitat loss and risk of disappearance. Brazilian Journal of Biology 67: 631-637. doi: 10.1590/S1519-69842007000200011

RotenberRy JT (1985) The role of habitat in avian community composition: Physiognomy or floristics? Oecologia 67: 213217. doi: 10.1007/BF00384286

SCARANO FR (2002) Structure, function and floristic relationships of plant communities in stressful habitats marginal to the Brazilian Atlantic Forest. Annals of Botany 90: 517-524. doi: 10.1093/aob/mcf189

Scarano FR, Rios RI, Esteves FA (1998) Tree species richness, diversity and flooding regime: case studies of recuperation after anthropic impact in Brazilian flood-prone forests. International Journal of Ecology and Environmental Sciences 24: 223-235.

Sick H (1997) Ornitologia Brasileira. Rio de Janeiro, Nova Fronteira, 912p.

Stein A, Kreft H (2014) Terminology and quantification of environmental heterogeneity in species-richness research. Biological Reviews 90: 815-836. doi: 10.1111/brv.12135
Stein A, Gerstner K, Kreft H (2014) Environmental heterogeneity as a universal driver of species richness across taxa, biomes and spatial scales. Ecology Letters 17: 866-880. doi: 10.1111/ele.12277

SouZA AF, MARTINS FR (2005) Spatial variation and dynamics of flooding, canopy openness, and structure in a Neotropical swamp forest. Plant Ecology 180: 161-173. doi: 10.1007/ s11258-004-7811-7

Sylvestre LS, Rosa MMT (2002) Manual metodológico para estudos botânicos na Mata Atlântica. Seropédica, Universidade Federal Rural do Rio de Janeiro, 123p.

TAulman JF, SMith KG (2002) Habitat mapping for bird conservation in North America. Bird Conservation International 12: 281-309. doi: 10.1017/S0959270902002186

Terborgh J (1985) Habitat selection in Amazon birds, p. 311-338. In: Cody ML (Ed.) Habitat selection in birds. New York, Academic Press, 558p.

Tews J, Brose U, Grimm V, Tielbörger K, Wichmann MC, Schwager M, JeLTsch F (2004) Animal species diversity driven by habitat heterogeneity/diversity: the importance of keystone structures. Journal of Biogeography 31: 79-92. doi: 10.1046/j.03050270.2003.00994.x

Turner W, Spector S, Gardiner N, Fladeland M, Sterling E, Steininger M (2003) Remote sensing for biodiversity, science and conservation. Trends in Ecology \& Evolution 18: 306-314. doi: 10.1016/S0169-5347(03)00070-3

Van Sluys M, Rocha CFD, Hatano FH, Boquimpani-Freitas L, Marra RV (2004) Anfíbios na Restinga de Jurubatiba: composição e história natural, p. 165-178. In: Rocha CFD, Esteves FA, SCARANO FR (Eds.) Pesquisas ecológicas de longa duração na Restinga de Jurubatiba: Ecologia, História Natural e Conservação. São Carlos, RiMa, 374p.

WILKINSON L (1990) SYSTAT: the system for statistics. Evanston, Systat Software.

Ye X, SKIDMORE AK, EANG T (2013) Within-patch habitat quality determines the resilience of specialist species in fragmented landscapes. Landscape Ecology 28: 135-147. doi: 10.1007/ s10980-012-9826-0

Submitted: 21 December 2015

Received in revised form: 19 April 2016

Accepted: 21 June 2016

Editorial responsibility: Luís Fábio Silveira

Author Contributions: VSMG and MASA designed the experiments; VSMG, MASA and MBV conducted the experiments; VSMG, MASA, MBV, BAL and CCCM analyzed the data and wrote the paper. MASA provided financial support. Competing Interests: The authors have declared that no competing interests exist. 
Appendix 1. Bird species occurrence in each study site in the Parque Nacional da Restinga de Jurubatiba (Taxonomy follows CBRO 2014). Source of record: $\mathrm{n}=$ nets, $\mathrm{o}=$ observations, $\mathrm{v}=$ voice recording. Feeding habit: $\mathrm{S}=$ seedeater, $\mathrm{F}=$ frugivorous, $\mathrm{I}=$ insectivorous, $\mathrm{N}=$ nectarivorous, $C=$ carnivorous, based on SICK (1997) and the authors experience - predominant items. FF $=$ flooded forest, DF $=$ dry forest, OS = open scrub, CS = closed scrub.

\begin{tabular}{|c|c|c|c|c|c|c|}
\hline Family/Species & English names & Feeding habit & $\mathrm{FF}$ & DF & OS & CS \\
\hline \multicolumn{7}{|l|}{ Tinamidae } \\
\hline Crypturellus tataupa (Temminck, 1815) & Tataupa Tinamou & FS & v & v & & \\
\hline \multicolumn{7}{|l|}{ Cracidae } \\
\hline Penelope superciliaris Temminck, 1815 & Rusty-margined Guan & $\mathrm{FI}$ & o & & & \\
\hline \multicolumn{7}{|l|}{ Columbidae } \\
\hline Columbina minuta (Linnaeus, 1766) & Plain-breasted Ground-Dove & S & & & $\mathrm{n}$ & $\mathrm{n}$ \\
\hline Columbina talpacoti (Temminck, 1811) & Ruddy Ground-Dove & S & & & $\mathrm{n}$ & $\mathrm{n}$ \\
\hline Columbina picui (Temminck, 1813) & Picui Ground-Dove & $\mathrm{s}$ & & & & $\mathrm{n}$ \\
\hline Claravis pretiosa (Ferrari-Perez, 1886) & Blue Ground-Dove & s & & & $\mathrm{n}$ & \\
\hline Patagioenas speciosa (Gmelin, 1789) & Scaled Pigeon & SF & o & & & \\
\hline Zenaida auriculata (Des Murs, 1847) & Eared Dove & s & & & & $\mathrm{n}$ \\
\hline Leptotila verreauxi Bonaparte, 1855 & White-tipped Dove & FS & v & v & $n, v$ & $n, v$ \\
\hline Geotrygon montana (Linnaeus, 1758) & Ruddy Quail-Dove & FS & & $\mathrm{n}$ & & \\
\hline \multicolumn{7}{|l|}{ Cuculidae } \\
\hline Coccyzus melacoryphus Vieillot, 1817 & Dark-billed Cuckoo & $\mathrm{Cl}$ & & & $\mathrm{n}$ & $\mathrm{n}$ \\
\hline Coccyzus americanus (Linnaeus, 1758) & Yellow-billed Cuckoo & $\mathrm{Cl}$ & o & & $\mathrm{n}$ & $\mathrm{n}, \mathrm{o}$ \\
\hline \multicolumn{7}{|l|}{ Trochilidae } \\
\hline Phaethornis sp. & & N & & o & & \\
\hline Eupetomena macroura (Gmelin, 1788) & Swallow-tailed Hummingbird & N & & & $\mathrm{n}$ & $n, v$ \\
\hline Amazilia fimbriata (Gmelin, 1788) & Glittering-throated Emerald & N & $\mathrm{n}$ & $\mathrm{n}$ & $\mathrm{n}$ & $n, v$ \\
\hline Amazilia sp. & & N & & & $\mathrm{n}$ & $\mathrm{n}$ \\
\hline \multicolumn{7}{|l|}{ Alcedinidae } \\
\hline Chloroceryle aenea (Pallas, 1764) & American Pygmy Kingfisher & $\mathrm{Cl}$ & $\mathrm{n}$ & & & \\
\hline \multicolumn{7}{|l|}{ Picidae } \\
\hline Picumnus cirratus Temminck, 1825 & White-barred Piculet & IF & o & & $\mathrm{n}$ & $\mathrm{n}, \mathrm{o}$ \\
\hline Colaptes campestris (Vieillot, 1818) & Campo Flicker & IF & & & & v \\
\hline Celeus flavescens (Gmelin, 1788) & Blond-crested Woodpecker & IF & $0, v$ & $0, v$ & $\mathrm{n}$ & \\
\hline \multicolumn{7}{|l|}{ Cariamidae } \\
\hline Cariama cristata (Linnaeus, 1766) & Red-legged Seriema & $\mathrm{Cl}$ & & v & v & v \\
\hline \multicolumn{7}{|l|}{ Psittacidae } \\
\hline Amazona amazonica (Linnaeus, 1766) & Orange-winged Parrot & $\mathrm{Fl}$ & & $0, v$ & $0, v$ & o \\
\hline \multicolumn{7}{|l|}{ Thamnophilidae } \\
\hline Myrmotherula axillaris (Vieillot, 1817) & White-flanked Antwren & 1 & $\mathrm{n}, \mathrm{o}, \mathrm{v}$ & $n, o$ & & \\
\hline Formicivora rufa (Wied, 1831) & Rusty-backed Antwren & 1 & & & $n, o, v$ & $\mathrm{n}, \mathrm{o}$ \\
\hline Thamnophilus ambiguus Swainson, 1825 & Sooretama Slaty-Antshrike & I & $n, o, v$ & $n, o, v$ & $\mathrm{n}$ & \\
\hline \multicolumn{7}{|l|}{ Furnariidae } \\
\hline Furnarius figulus (Lichtenstein, 1823) & Wing-banded Hornero & 1 & & & $\mathrm{n}$ & \\
\hline \multicolumn{7}{|l|}{ Pipridae } \\
\hline Dixiphia pipra (Linnaeus, 1758) & White-crowned Manakin & $\mathrm{Fl}$ & $\mathrm{n}$ & $n, o$ & & \\
\hline \multicolumn{7}{|l|}{ Tityridae } \\
\hline Pachyramphus polychopterus (Vieillot, 1818) & White-winged Becard & I & & & & $\mathrm{n}$ \\
\hline \multicolumn{7}{|l|}{ Rhynchocyclidae } \\
\hline Tolmomyias sulphurescens (Spix, 1825) & Yellow-olive Flycatcher & I & o & & & o \\
\hline Tolmomyias flaviventris (Wied, 1831) & Yellow-breasted Flycatcher & । & $\mathrm{n}$ & & $\mathrm{n}$ & \\
\hline Todirostrum cinereum (Linnaeus, 1766) & Common Tody-Flycatcher & 1 & & & & $n, o, v$ \\
\hline Myiornis auricularis (Vieillot, 1818) & Eared Pygmy-Tyrant & 1 & & $n, o$ & & \\
\hline \multicolumn{7}{|l|}{ Tyrannidae } \\
\hline Euscarthmus meloryphus Wied, 1831 & Tawny-crowned Pygmy-Tyrant & । & & & o & \\
\hline
\end{tabular}


Appendix 1. Continued.

\begin{tabular}{|c|c|c|c|c|c|c|}
\hline Family/Species & English names & Feeding habit & $\mathrm{FF}$ & DF & OS & CS \\
\hline Camptostoma obsoletum (Temminck, 1824) & Southern Beardless-Tyrannulet & I & o & & $n, o, v$ & $\mathrm{n}, \mathrm{o}, \mathrm{v}$ \\
\hline Elaenia flavogaster (Thunberg, 1822) & Yellow-bellied Elaenia & $\mathrm{FI}$ & v & & $\mathrm{n}, \mathrm{o}$ & $n, o, v$ \\
\hline Elaenia chilensis Hellmayr, 1927 & Chilean Elaenia & $\mathrm{FI}$ & & & & $\mathrm{n}$ \\
\hline Elaenia cristata Pelzeln, 1868 & Plain-crested Elaenia & $\mathrm{FI}$ & & & $\mathrm{n}$ & $\mathrm{n}$ \\
\hline Elaenia chiriquensis Lawrence, 1865 & Lesser Elaenia & $\mathrm{FI}$ & & & $\mathrm{n}$ & $\mathrm{n}$ \\
\hline Elaenia obscura (d'Orbigny \& Lafresnaye, 1837) & Highland Elaenia & $\mathrm{FI}$ & & & & $\mathrm{n}$ \\
\hline Attila rufus (Vieillot, 1819) & Gray-hooded Attila & 1 & o & & & \\
\hline Cnemotriccus fuscatus (Wied, 1831) & Fuscous Flycatcher & I & $n, o$ & $\mathrm{n}$ & & \\
\hline Myiarchus tyrannulus (Statius Muller, 1776) & Brown-crested Flycatcher & 1 & $\mathrm{n}$ & & $\mathrm{n}, \mathrm{o}$ & $\mathrm{n}, \mathrm{o}$ \\
\hline Pitangus sulphuratus (Linnaeus, 1766) & Great Kiskadee & IFC & $n, o, v$ & & $n, v$ & $\mathrm{n}, \mathrm{o}, \mathrm{v}$ \\
\hline Myiodynastes maculatus (Statius Muller, 1776) & Streaked Flycatcher & I & & & $\mathrm{n}$ & \\
\hline Myiozetetes similis (Spix, 1825) & Social Flycatcher & IF & o & & & \\
\hline Tyrannus melancholicus Vieillot, 1819 & Tropical Kingbird & IF & o & o & $n, o$ & $\mathrm{n}, \mathrm{o}$ \\
\hline Satrapa icterophrys (Vieillot, 1818) & Yellow-browed Tyrant & 1 & & & & $\mathrm{n}, \mathrm{o}$ \\
\hline \multicolumn{7}{|l|}{ Vireonidae } \\
\hline Vireo chivi (Vieillot, 1817) & Chivi Vireo & $\mathrm{FI}$ & $\mathrm{n}, \mathrm{o}, \mathrm{v}$ & $\mathrm{n}, \mathrm{o}, \mathrm{v}$ & & $n, o$ \\
\hline Hylophilus thoracicus Temminck, 1822 & Lemon-chested Greenlet & $\mathrm{FI}$ & & & & $\mathrm{n}$ \\
\hline \multicolumn{7}{|l|}{ Troglodytidae } \\
\hline Troglodytes musculus Naumann, 1823 & Southern House Wren & 1 & & & $\mathrm{n}$ & $n, v$ \\
\hline Pheugopedius genibarbis (Swainson, 1838) & Moustached Wren & 1 & $\mathrm{n}, \mathrm{o}, \mathrm{v}$ & $\mathrm{n}$ & & \\
\hline \multicolumn{7}{|l|}{ Turdidae } \\
\hline Turdus flavipes Vieillot, 1818 & Yellow-legged Thrush & $\mathrm{FI}$ & $\mathrm{n}$ & $\mathrm{n}$ & $\mathrm{n}$ & $\mathrm{n}$ \\
\hline Turdus amaurochalinus Cabanis, 1850 & Creamy-bellied Thrush & $\mathrm{FI}$ & $\mathrm{n}, \mathrm{o}$ & & $\mathrm{n}$ & $\mathrm{n}, \mathrm{o}$ \\
\hline Turdus albicollis Vieillot, 1818 & White-necked Thrush & $\mathrm{FI}$ & $\mathrm{n}$ & $\mathrm{n}$ & & \\
\hline \multicolumn{7}{|l|}{ Mimidae } \\
\hline Mimus gilvus (Vieillot, 1807) & Tropical Mockingbird & $\mathrm{FI}$ & & & $n, o, v$ & $n, o, v$ \\
\hline Mimus saturninus (Lichtenstein, 1823) & Chalk-browed Mockingbird & $\mathrm{FI}$ & & & o & \\
\hline Zonotrichia capensis (Statius Muller, 1776) & Rufous-collared Sparrow & $\mathrm{FI}$ & & & $n, o, v$ & $\mathrm{n}, \mathrm{o}, \mathrm{v}$ \\
\hline \multicolumn{7}{|l|}{ Parulidae } \\
\hline Setophaga pitiayumi (Vieillot, 1817) & Tropical Parula & 1 & & $v$ & o & o \\
\hline \multicolumn{7}{|l|}{ Icteridae } \\
\hline Cacicus haemorrhous (Linnaeus, 1766) & Red-rumped Cacique & $\mathrm{FI}$ & o & & & $\mathrm{n}$ \\
\hline Molothrus bonarienesis (Gmelin, 1789) & Shiny Cowbird & 1 & & & & o \\
\hline \multicolumn{7}{|l|}{ Thraupidae } \\
\hline Coereba flaveola (Linnaeus, 1758) & Bananaquit & $\mathrm{NI}$ & $\mathrm{n}, \mathrm{o}$ & o & $\mathrm{n}$ & $n, o$ \\
\hline Nemosia pileata (Boddaert, 1783) & Hooded Tanager & $\mathrm{FI}$ & & & $\mathrm{n}, \mathrm{o}$ & $\mathrm{n}$ \\
\hline Tachyphonus coronatus (Vieillot, 1822) & Ruby-crowned Tanager & $\mathrm{FI}$ & o & $\mathrm{n}$ & $\mathrm{n}$ & $\mathrm{n}$ \\
\hline Ramphocellus bresilius (Linnaeus, 1766) & Brazilian Tanager & $\mathrm{FI}$ & $\mathrm{n}$ & & & $\mathrm{n}$ \\
\hline Lanio pileatus (Wied, 1821) & Pileated Finch & $\mathrm{FI}$ & & & $\mathrm{n}, \mathrm{o}$ & $n, o, v$ \\
\hline Tangara sayaca (Linnaeus, 1766) & Sayaca Tanager & $\mathrm{FI}$ & & & $\mathrm{n}, \mathrm{o}$ & $\mathrm{n}$ \\
\hline Tangara peruviana (Desmarest, 1806) & Black-backed Tanager & $\mathrm{FI}$ & & o & $\mathrm{n}, \mathrm{o}$ & $\mathrm{n}, \mathrm{o}$ \\
\hline Schistochlamys ruficapillus (Vieillot, 1817) & Cinnamon Tanager & $\mathrm{FI}$ & & & o & \\
\hline Cyanerpes cyaneus (Linnaeus, 1766) & Red-legged Honeycreeper & $\mathrm{FI}$ & $\mathrm{n}, \mathrm{o}$ & $0, v$ & $\mathrm{n}$ & $\mathrm{n}, \mathrm{o}$ \\
\hline Haplospiza unicolor Cabanis, 1851 & Uniform Finch & $S$ & & $\mathrm{n}$ & & \\
\hline Sicalis luteola (Sparrman, 1789) & Grassland Yellow-Finch & $S$ & & & & $v$ \\
\hline Volatinia jacarina (Linnaeus, 1766) & Blue-black Grassquit & $S$ & & & & o \\
\hline \multicolumn{7}{|l|}{ Fringilidae } \\
\hline Euphonia chlorotica (Linnaeus, 1766) & Purple-throated Euphonia & $\mathrm{FI}$ & o & o & $\mathrm{n}, \mathrm{o}$ & $\mathrm{n}, \mathrm{o}$ \\
\hline Total 74 & & & 33 & 25 & 42 & 49 \\
\hline \multirow{2}{*}{ Exclusive species } & Site & & 5 & 4 & 6 & 12 \\
\hline & Habitat (Forest vs. Scrub) & & \multicolumn{2}{|c|}{15} & \multicolumn{2}{|c|}{32} \\
\hline
\end{tabular}


Appendix 2. Bird captures in each study site in the Parque Nacional da Restinga de Jurubatiba (Taxonomy follows CBRO 2014). (FF) flooded forest, (DF) dry forest, (OS) open scrub, (CS) closed scrub.

\begin{tabular}{|c|c|c|c|c|c|}
\hline Family/Species & English names & $\mathrm{FF}$ & DF & OS & CS \\
\hline \multicolumn{6}{|l|}{ Columbidae } \\
\hline Columbina minuta & Plain-breasted Ground-Dove & & & 23 & 11 \\
\hline Columbina talpacoti & Ruddy Ground-Dove & & & 7 & 66 \\
\hline Columbina picui & Picui Ground-Dove & & & & 1 \\
\hline Claravis pretiosa & Blue Ground-Dove & & & 1 & \\
\hline Zenaida auriculata & Eared Dove & & & & 1 \\
\hline Leptotila verreauxi & White-tipped Dove & & & 1 & 2 \\
\hline Geotrygon montana & Ruddy Quail-Dove & & 3 & & \\
\hline \multicolumn{6}{|l|}{ Cuculidae } \\
\hline Coccyzus melacoryphus & Dark-billed Cuckoo & & & 4 & 2 \\
\hline Coccyzus americanus & Yellow-billed Cuckoo & & & 1 & 1 \\
\hline \multicolumn{6}{|l|}{ Trochilidae } \\
\hline Eupetomena macroura & Swallow-tailed Hummingbird & & & 1 & 2 \\
\hline Amazilia fimbriata & Glittering-throated Emerald & 3 & 7 & 31 & 40 \\
\hline Amazilia sp. & & & & 1 & 3 \\
\hline \multicolumn{6}{|l|}{ Alcedinidae } \\
\hline Chloroceryle aenea & American Pygmy Kingfisher & 2 & & & \\
\hline \multicolumn{6}{|l|}{ Picidae } \\
\hline Picumnus cirratus & White-barred Piculet & & & 2 & 10 \\
\hline Celeus flavescens & Blond-crested Woodpecker & & & 1 & \\
\hline \multicolumn{6}{|l|}{ Thamnophilidae } \\
\hline Myrmotherula axillaris & White-flanked Antwren & 8 & 25 & & \\
\hline Formicivora rufa & Rusty-backed Antwren & & & 5 & 10 \\
\hline Thamnophilus ambiguus & Sooretama Slaty-Antshrike & 4 & 30 & 1 & \\
\hline \multicolumn{6}{|l|}{ Furnariidae } \\
\hline Furnarius figulus & Wing-banded Hornero & & & 1 & \\
\hline \multicolumn{6}{|l|}{ Pipridae } \\
\hline Dixiphia pipra & White-crowned Manakin & 1 & 13 & & \\
\hline \multicolumn{6}{|l|}{ Tityridae } \\
\hline $\begin{array}{l}\text { Pachyramphus } \\
\text { polychopterus }\end{array}$ & White-winged Becard & & & & 1 \\
\hline \multicolumn{6}{|l|}{ Rhynchocyclidae } \\
\hline Tolmomyias flaviventris & Yellow-breasted Flycatcher & 2 & & 2 & \\
\hline Todirostrum cinereum & Common Tody-Flycatcher & & & & 8 \\
\hline Myiornis auricularis & Eared Pygmy-Tyrant & & 1 & & \\
\hline \multicolumn{6}{|l|}{ Tyrannidae } \\
\hline \multicolumn{6}{|c|}{ Continues } \\
\hline
\end{tabular}

Appendix 2. Continued.

\begin{tabular}{|c|c|c|c|c|c|}
\hline Family/Species & English names & $\mathrm{FF}$ & DF & OS & CS \\
\hline Camptostoma obsoletum & Southern Beardless-Tyrannulet & & & 15 & 15 \\
\hline Elaenia flavogaster & Yellow-bellied Elaenia & & & 15 & 26 \\
\hline Elaenia chilensis & Chilean Elaenia & & & & 2 \\
\hline Elaenia cristata & Plain-crested Elaenia & & & 2 & 1 \\
\hline Elaenia chiriquensis & Lesser Elaenia & & & 5 & 14 \\
\hline Elaenia obscura & Highland Elaenia & & & & 2 \\
\hline Cnemotriccus fuscatus & Fuscous Flycatcher & 4 & 2 & & \\
\hline Myiarchus tyrannulus & Brown-crested Flycatcher & 1 & & 6 & 8 \\
\hline Pitangus sulphuratus & Great Kiskadee & 2 & & 3 & 9 \\
\hline Myiodynastes maculatus & Streaked Flycatcher & & & 1 & \\
\hline Tyrannus melancholicus & Tropical Kingbird & & & 5 & 6 \\
\hline Satrapa icterophrys & Yellow-browed Tyrant & & & & 2 \\
\hline \multicolumn{6}{|l|}{ Vireonidae } \\
\hline Vireo chivi & Chivi Vireo & 1 & 1 & & 1 \\
\hline Hylophilus thoracicus & Lemon-chested Greenlet & & & & 1 \\
\hline \multicolumn{6}{|l|}{ Troglodytidae } \\
\hline Troglodytes musculus & Southern House Wren & & & 3 & 6 \\
\hline Pheugopedius genibarbis & Moustached Wren & 6 & 1 & & \\
\hline \multicolumn{6}{|l|}{ Turdidae } \\
\hline Turdus flavipes & Yellow-legged Thrush & 4 & 1 & 10 & 17 \\
\hline Turdus amaurochalinus & Creamy-bellied Thrush & 4 & & 27 & 74 \\
\hline Turdus albicollis & White-necked Thrush & 1 & 1 & & \\
\hline \multicolumn{6}{|l|}{ Mimidae } \\
\hline Mimus gilvus & Tropical Mockingbird & & & 13 & 23 \\
\hline Zonotrichia capensis & Rufous-collared Sparrow & & & 27 & 50 \\
\hline \multicolumn{6}{|l|}{ Icteridae } \\
\hline Cacicus haemorrhous & Red-rumped Cacique & & & & 4 \\
\hline \multicolumn{6}{|l|}{ Thraupidae } \\
\hline Coereba flaveola & Bananaquit & 1 & 1 & 21 & 14 \\
\hline Nemosia pileata & Hooded Tanager & & & 2 & 3 \\
\hline Tachyphonus coronatus & Ruby-crowned Tanager & & 3 & 2 & 3 \\
\hline Ramphocellus bresilius & Brazilian Tanager & 1 & & & 2 \\
\hline Lanio pileatus & Pileated Finch & & & 5 & 12 \\
\hline Tangara sayaca & Sayaca Tanager & & & 3 & 3 \\
\hline Tangara peruviana & Black-backed Tanager & & & 7 & 12 \\
\hline Cyanerpes cyaneus & Red-legged Honeycreeper & 1 & & 6 & 2 \\
\hline Haplospiza unicolor & Uniform Finch & & 1 & & \\
\hline \multicolumn{6}{|l|}{ Fringilidae } \\
\hline Euphonia chlorotica & Purple-throated Euphonia & & & 1 & 12 \\
\hline
\end{tabular}

\section{ONLINE SUPPLEMENTARY MATERIAL}

About the Online Supplementary Material (available with the HTML version of the article at http://www.scielo.br/zool):

Figure S1. Snip of a satellite image of the Parque Nacional da Restinga de Jurubatiba region showing the four study sites (Original image: CBERS 2, CCD Sensor - Spectral Band 2 (green), Scale 1:35000. Acquisition on April 7th 2004, supplied by National Institute For Space Research - INPE, holder of Creative Commons License; http://www.dgi.inpe.br/CDSR). DMS shown are coordinates in the lower right edges of the figure. 